\title{
Hester Prynne and Nora Helmer: Two extraordinary women representatives in English Literature
}

\author{
Azmi Azam \\ Anglia Ruskin University Cambridge, England.
}

\begin{abstract}
This article aims to explore the representation of Hester Prynne in Nathaniel Hawthorne's The Scarlet letter and Nora Helmer in Henrik Ibsen's A Doll's House. Hester shows the conventional woman stereotype and under her silence she epitomizesextraordinary power of tolerance, patience, forgiveness and acceptance. On the other hand, Nora is a recalcitrant female individual who protests against the male chauvinist attitude and patriarchy dominance by leaving for home and family for self-respect. A comparative discussion will also be given to make arguments more logical. Comments of other critics will be placed for further comprehension.
\end{abstract}

Key words: Womanhood, feminism, male chauvinism, individuality, silence, tolerance, patience, recalcitrance, self-respect, reputation, society, domesticity.

\section{Analysis:}

The protagonist Hester Prynne is a traditional literary female character depicted by Nathaniel Hawthorn in The Scarlet Letter that created a great concern of feminism. She has done adultery and has been socially humiliated and isolated. She has been punished to wear the scarlet letter ' $\mathrm{A}$ ' on her dress and even the word has been inscribed on her grave. The matter of concern is in which sense she is condemned to such a brutal punishment. Honour is life for a woman and taking it away is a heinous crime. The Puritan society of that time made her suffer with insults in order to teach other woman to secure their modesty in absence of their husbands. But is it a lesson enough where the main culprit, clergyman Arthur Dimmesdale, is escaped and the victims, Hester and her illegitimate child Pearl, only suffer. Hester has done what every tradition society expects a woman to do. She conceals the name of the father of Pearl and abandoned the shame all over her life silently.

She proved a woman of greater tolerance and higher patience but is it right to condemn her. Her husband left her immediately after the marriage and was lost for several years which generally marked him dead. In such a case, if a woman loves someone else and after getting pregnant the man refuses to marry her and give legitimacy to the child, the woman must not be considered guilty rather than a victim. She did what every ordinary woman must have done naturally. She moved on for a better life. The society wanted her to live a life of a widow of such an irresponsible man who left her suddenly. The readers are informed that Hester's husband is alive and he does come back at the very starting of the novel but turns revengeful marking Hester's adultery and disguises himself from everyone. Therefore, it turns evident that Chillingworth intentionally avoids the responsibility of his wife and his male ego provokes him to commit brutal subjective tortures to the poor helpless Hester. Hester remains silent from the beginning till the end in order to save Arthur Dimmesdale's public reputation as well as Chillingworth's actual identity as well. Her intolerable pain and suffrage made Dimmesdale ashamed of himself and he suffers from guilty conscience. In this regard, critic Claudia Durst Johnson says:

The very fact that it is the pious Mr. Dimmesdale who has committed one of the worst of sins, according to the Puritans, underscores their tenet that every human being, whether pious or humanitarian, is depraved and corrupt. He himself struggles with the irony that he is considered to be a man of God, yet hides from them the fact that he is human, which is to say sinful. (Johnson, 1997, p.53)

She fights silently marking her extraordinary power of forbearance. At the end, she dies at the end of the novel but the letter is written on her grave.This act of the Puritans highlights greater feminist concern. We do not know whether Dimmesdale's grave also has this letter inscribed or not. We can guess he does not have because if he has it, the novelist should have mentioned it. Then it is a matter of regret that Hester carries the burden of shame even after her death. We may have a consolation that the period of Puritan era limits woman liberty and thus a woman has no other choice but to be punished the way Hester has. Though, we cannot ignore the fact that during that age, the supreme authority was on woman like Queen Victorian and later Queen 
Elizabeth. If a woman can control the throne all by herself, why can not a woman protest against social and ideological orthodoxy? Regarding Hester's character, critic Gary Scharnhorst says:

Hester's character is of a strong mould. Without being unwomanly, she is of far less effeminate texture than the man she loved so truly, and for whom she suffered so bravely. Under the hard Puritan treatment she somewhat hardens. The blazing brand upon her breast does not melt, but indurates her heart. (1992, p.59)

Again, Pearl, Dimmesdale and Hester's illegitimate daughter, is a symbol of sin and adultery in the sense that she leads Dimmesdale and Hester to their confession and the acceptance of their sins. This innocent and beautiful daughter has sometimes demon like traits. She is also the only living symbol of the scarlet letter "A". Initially Pearl is the symbol of Hester's public punishment for her adultery. As the novel progresses and Pearl matures, she symbolizes the deterioration of Hester's like by constantly asking her about the scarlet letter "A". Pearl in a sense wants her mother to live up to her sin and, she achieves this by constantly asking her about the scarlet letter. Another piece of evidence that shows how Pearl symbolizes the sin Hester has committed, is when the town government wants to take Pearl away from her, Reverend Dimmesdale convinces the government that Pearl is a living reminder of her sin. This is essentially true, Hester without Pearl is like having Hester without sin.

Pearl is not only a symbol of Hester but also a symbol to Dimmesdale's lust which is a forbidden sin for a clergyman. Pearl will not let him into her life until he accepts his sin. She wants him as a father but will not let him be so until he will not hide his sin in public. Pearl knows that Dimmesdale will not be seen holding her hand in the public eye and this bothers her. As we reach to the final of the story, Dimmesdale confesses his sin and he has a sense of happiness and self-peace almost immediately. Pearl has longed for his public love and affection and in the closing scenes she receives it. With all this at hand Pearl cries for the first time in the book. Therefore, in The Scarlet Letter, Pearl symbolizes Hester and Dimmesdale's connection in many ways. Pearl is the symbol of her mother's sin. Not only is she this great symbol for her mother, but Dimmesdale also. Most important Pearl leads Dimmesdale and Hester to the acceptance of their sin.

On the other hand, Nora Helmer in Henrik Ibsen's A Doll's House is a recalcitrant woman of the brave new world who dares to stand against the patriarchy dominance of the society and even of the domestic life. She is also a victim of the male chauvinist society. He committed forgery to save the life of her husband and is being blackmailed by her husband's colleague. Moreover, when her husband comes to know the truth, he verbally assaults her that evokes the self-respect ego of Nora and she decides to leave Torvald forever. She not only leaves her husband but also the house and children too. Such a bold attempt by a housewife creates a great shock to the readers and she is condemned to be a woman of irresponsibility but also marked as a stern feminist.

The inferior role of Nora is extremely important as she is oppressed by a variety of tyrannical social conventions. Ibsen in his work depicts the role of women as subordinate in order to emphasize their role in society. Nora is oppressed by the manipulation from Torvald as he maintains a very typical relationship with society. He is a smug bank manager. With his job arrive many responsibilities. He often treats his wife as if she is one of these responsibilities. Torvald is very authoritative and puts his appearance, both social and physical, ahead of his wife that he supposedly loves. Torvald is a man that is worried about his reputation, and cares little about his wife's feelings.

Nora and Torvald's relationship, on the outside seems to be a blissful. Nora is treated like a child in this relationship, but as the play develops she begins to understand how pretentious her marriage is. Torvald sees Nora's only as being the subservient and loving wife. To him, she is only a possession, a doll of his own choice. Torvald calls Nora by pet-names and speaks down to her because he thinks that she is not intelligent enough and that she cannot think on her own with intellectuality and maturity. Whenever she begins to voice an opinion Torvald quickly drops the pet-names and insults her as a woman through euphemistic comments. Torvald is a typical husband in his society. He denied Nora the right to think and act the way she wished. He required her to act like an imbecile and insisted upon the rightness of his view in all matters.

Nora is a dynamic character in this play. She goes through many changes and develops more than any other character in the literary work. Nora, at the beginning and throughout most of the play, is inauthentic character. An inauthentic identity is when a person believes their personality is identical to their behaviour. However subconsciously they know that it is not true. Nora was inauthentic because her situation was all that she was ever exposed to. She is a grown woman that was pampered all her life by men. Nora was spoon-fed all of her life by her father and husband. She believes in Torvald unquestionably, and has always believed that he was her idol. She is the perfect image of a doll wife who revels in the thought of luxuries that she can afford 
because she is married. She is very flirtatious, and constantly engages in childlike acts of disobedience such as little lies about things such as whether or not she bought macaroons. Nora goes through life with the illusion that everything is perfect in this world.

When a woman of that time loves, as Nora thinks, she does everything without judgement to protect it. She will sacrifice herself for the family. Her purpose in life is to be happy for her husband and children. Nora did believe that she loved Torvald and was happy. She had a passionate and devoted heart that was willing to do almost anything for her husband. At first she did not understand that these feelings were not reciprocated. Torvald does not want a wife who will challenge him with her own thoughts and actions. The final confrontation between the couple involves more oppression by Torvald, but by this time Nora has realized the situation he wishes to maintain. Torvald calls her a "featherbrained woman" and "blind, incompetent child" even though she saved him with her life. Nora expected Torvald to be grateful to her. This does not happen. The fury Nora saw after Torvald's opening of the letter showed Nora a strange man. Someone she had not been wife to, someone she did not love. Their marriage is fake and mutually beneficial because of their social status. They are not really in love. It is now that she can begin to apprehend her forgery was wrong, not because it was illegal, but because it was for an unworthy cause.

This is when the readers see Nora embark into her transformation of her authentic character. Nora decides that the only way to fix the situation is to leave Torvald and her children and find herself individualistically. Slowly Nora's character is forced to discontinue her inauthentic role of a doll and seek out her individuality, her new authentic identity. She comes to realize that her whole life has been a lie. She lived her life pretending to be the old Nora, and hid the changed woman she had become. The illusion of the old Nora continues well after she becomes a new person. When she realizes that responsibilities for herself are more important, Nora slams the door on not just Torvald but on everything that happened in her past. It took time to evolve into a new person, but after she did she became a person who could not stand to be oppressed by Torvald any longer. Ibsen uses the idea of a "doll" because a doll always maintains the same look, no matter what the situation. A doll must do whatever the controller has them do. Dolls are silent and never express opinions or actually accomplish anything without the aid of others. This doll is Nora's inauthentic identity.

Her authentic identity is in the process of being built while Torvald calls Nora his "little lark", his "little squirrel", and a child. Nora grows even stronger. It is complete and presented to the readers when Nora stands up to Torvald and does the opposite of what he wants. Nora tells Helmer at the end of the play that, "I have to try to educate myself. You can't help me with that. I've got to do it alone. And that's why I'm leaving you now". She does not tolerate Torvald's patronizing tone or allow him to operate her any longer. Nora must follow her own convictions now and decide for herself what her life will be in the future. Her rebirth has led to her own independence. Another man will never again control her and she is now free of her controlling husband.

Thus, we can state that Nora Helmer is a character struggling to realize her authentic identity. Her husband Torvald has always established her identity. Throughout the play Torvald was condescending towards Nora and forced her to act and look in a way that pleased him. Nora allowed Torvald to play dress up with her and no matter what the situation Nora has to consistently remain Torvald's quiet, happy, little doll. Nora ends her doll life by leaving her doll house to learn and explore on her own. She is no longer a doll under the control of her master. Hester and Nora are sternly opposite to each other but both of them represent extraordinary zeal and feminist power in their own respective abilities. Whether they succeed or not, that is not the crucial matter but the way they fought against the oppression, silently or verbally, is a matter of feminist concerns.

[1]. Garrett, S., 1992.Gender. London: Routledge.

\section{Bibliography}

[2]. Basow. S.A., 1992, $3^{\text {rd }}$ ed., Gender: Stereotypes and Roles. California: Brooks/Cole Publishing Company.

[3]. Lancaster, R.N., and Leonardo, M., eds, 1997. The Gender Sexuality: Reader. London: Routledge.

[4]. Ledger, S., 1997.The New Woman: Fiction and Feminism at the fin de siècle. Manchester: Manchester University Library.

[5]. Scharnhorst, G., ed., 1992.The Critical response to Nathaniel Hawthorne's The Scarlet Letter. London: Greenwood.

[6]. Johnson, C.D., 1997. Understanding The Scarlet Letter. London: Greenwood press.

[7]. Crowley, D., ed., 1970.Hawthorne The Critical Heritage. London: Routledge.

[8]. James, H., 1999. Hawthorne. Nottingham: Nottingham Trent University.

[9]. Waggoner, H.H., 1999.Hawthorne: A Critical Study. London: Oxford University press.

[10]. Swann, C., 1998. Nathaniel Hawthorne: Tradition and Revolution. Cambridge: Cambridge University press.

[11]. Scharnhorst, G., ed., 1992.The Critical Response to Nathaniel Hawthorne. London: Greenwood.

[12]. Gerber, J.C., ed., Twentieth Century Interpretations of The Scarlet Letter. New Jersey: Englewood Cliffs.

[13]. Aristotle, 1960.The Poetics: "Longliness" On the Sublime Demetrius on Style. Cambridge : William Heinemann ltd.

[14]. Cunningham, G., 1978. The New Woman and the Victorian Novel. London: Macmillan.

[15]. Coward, R., n. d., 'Female Desire: Women's Sexuality Today'. In: M. Eagleton., ed., 1994. $2^{\text {nd }}$ ed.Feminist Literary Theory: A Reader. Cambridge: Blackwell Publishers. 
[16]. Eagleton, M.,ed., 1996.2 $2^{\text {nd }}$ ed., Feminist Literary Theory. Cambridge: Blackwell Publishers.

[17]. Furman, N., n. d., 'The politics of language: beyond the gender principle?'.In G. Greene and C. Kahn, eds., 1985.Making a Difference: Feminist Literary Criticism. London: Methuen.

[18]. Flint, K., 1987. The Victorian Novelist: Social Problems and Social Change. New York: Methuen.

[19]. Gilmour, R., 1981. The Idea of the Gentleman in the Victorian Novel. London: George Allen \& Unwin.

[20]. Showalter, E. n. d. 'A Literature of Their Own'. In: M. Eagleton. ed. 1989.Feminist Literary Theory: A Reader. Oxford: Basil Blackwell.

[21]. Tompkins, J., 'Me and My Shadow'. In: L. Kauffman, ed. 1989. Gender and Theory: Dialogues on Feminist Criticism. Oxford: Basil Blackwell.

[22]. Todd, J., 1991. Feminist Literary History. Cambridge: Polity Press.

[23]. Bryan, G.B. 1984. An Ibsen Companion. London: Greenwood press.

[24]. Chanter, T., 2006. Gender: Key Concepts in Philosophy. London: Continuum International Publishing Group.

[25]. Mcleish, K. and Mulrine, S. trans. 2005. Ibsen Three Plays. London: Nick Horn Books.

[26]. McFarlane, J., ed., 1994. The Cambridge Companion to Ibsen. Cambridge: Cambridge University press.

[27]. Tornqvist, E., 1995. Ibsen: A Doll's House. Cambridge: Cambridge University press.

[28]. Templeton, J., 2001. Ibsen's Women. Cambridge: Cambridge University press.

[29]. Ibsen, H., A Doll's House. In Mcguinness, F., ed. 1996. Henrik Ibsen: A Doll's House. London: Faber and Faber.

[30]. McFarlane, J., 1989. Ibsen and Meaning. Oslo: Norvik Press.

[31]. Chamberlain, J.S., 1982. Ibsen: The Open Vision. London: Athlone.

[32]. Theoharis, T.C., 1999. Ibsen's Drama. London: Macmillan.

[33]. Mandel, S., ed.,.1985. Ibsen's Heroines.Yew York: Limelight.

[34]. Meyer, M., ed., 1990. Ibsen Plays: Two. London: Methuen.

[35]. Lenz, C.R.S; Greene, G., and Neely, C.T., eds., 1983.The Woman's Part: Feminist Criticism of Shakespeare. Chicago: University of Illinois.

[36]. Massai.,S., ed. 2005. World-Wide Shakespeares: Local Appreciation in film and performance.London: Routledge.

[37]. McDonald, R., ed. 2011. Shakespeare: An Anthology of Criticism and Theory 1945-2000. London: Blackwell.

[38]. Mitchell, J., and Oakley, A., 1994. What is Feminism?. London: Blackwell.

[39]. Summers, A., 2000.Female Lives, Moral States. London: Threshold press.

[40]. Ledger, S., 1997.The New Women. Manchester: Manchester University press.

[41]. Perkin, J., 1993. Victorian Women. Cambridge: Cambridge University press.

[42]. Levine, P. 1994. Victorian Feminism:1850-1900. Florida: University Press of Florida.

[43]. Apetrei, S., 2010.Women, Feminism and Religion in Early Enlightenment England. Cambridge: Cambridge University press.

[44]. Kelly, J., 1984. Women, History and Theory.Chikago: University Press of Chicago.

[45]. Jones, V.,1991. Women in the Eighteenth Century. London: Routledge.

[46]. Swindells, J., 1985. Victorian Writing \& Working Women. Oxford: Basil Blackwell. 